Published in final edited form as:

Vaccine. 2014 May 30; 32(26): 3274-3284. doi:10.1016/j.vaccine.2014.03.087.

\title{
In vivo immunogenicity of Tax 11-19 epitope in HLA-A2/DTR transgenic mice: implication for dendritic cell-based anti-HTLV-1 vaccine
}

\author{
Divya Sagar ${ }^{1}$, Shet Masih ${ }^{1}$, Todd Schell ${ }^{2}$, Steven Jacobson ${ }^{3}$, Joseph D. Comber ${ }^{4}$, Ramila \\ Philip $^{4}$, Brian Wigdahl ${ }^{5}$, Pooja Jain ${ }^{1, *}$, and Zafar K. Khan ${ }^{1, *}$ \\ ${ }^{1}$ Department of Microbiology and Immunology, Drexel Institute for Biotechnology \& Virology \\ Research, Drexel University College of Medicine, Philadelphia, Pennsylvania, USA \\ ${ }^{2}$ Department of Microbiology and Immunology, The Pennsylvania State University College of \\ Medicine, Hershey, Pennsylvania, USA \\ ${ }^{3}$ Viral Immunology Section, Neuroimmunology Branch, National Institutes of Health, Bethesda, \\ MD, USA \\ ${ }^{4}$ Immunotope, Inc, Doylestown, Pennsylvania, USA \\ ${ }^{5}$ Department of Microbiology and Immunology, and the Center for Molecular Virology and \\ Translational Neuroscience, Institute for Molecular Medicine and Infectious Disease, Drexel \\ University College of Medicine, Philadelphia, Pennsylvania, USA
}

\section{Abstract}

Viral oncoprotein Tax plays key roles in transformation of human T-cell leukemia virus (HTLV-1)-infected T cells leading to adult T-cell leukemia (ATL), and is the key antigen recognized during HTLV-associated myelopathy (HAM). In HLA-A2+ asymptomatic carriers as well as ATL and HAM patients, Tax(11-19) epitope exhibits immunodominance. Here, we evaluate CD8 T-cell immune response against this epitope in the presence and absence of dendritic cells (DCs) given the recent encouraging observations made with Phase 1 DC-based vaccine trial for ATL. To facilitate these studies, we first generated an HLA-A2/DTR hybrid

\footnotetext{
(C) 2014 Elsevier Ltd. All rights reserved.

*Correspondence: Drs. Jain and Khan, Department of Microbiology \& Immunology and Drexel Institute for Biotechnology \& Virology Research, Drexel University College of Medicine, 3805 Old Easton Road, Doylestown, PA 18902, USA., pjain@drexelmed.edu; 215-589-6441, zkhan@drexelmed.edu; 215-589-6431, Fax No.: 215-489-4920.

Conflict of interest

The authors declare that they have no competing interests.

Authors' contributions

DS, SM, TS, PJ, and ZKK contributed to the conception and design of the paper. DS and SM performed the experimental work with the direct supervisory assistance from PJ and ZKK. JDC assisted with MILLIPLEX magnetic bead assay. DS, SM, PJ, and ZKK drafted the manuscript. TS, SJ, BW, PJ, and ZKK thoroughly read and enriched the manuscript for important intellectual content and gave final approval of the version to be published. JDC and RP gave several inputs during the revision process and thoroughly reviewed the revised manuscript.

Publisher's Disclaimer: This is a PDF file of an unedited manuscript that has been accepted for publication. As a service to our customers we are providing this early version of the manuscript. The manuscript will undergo copyediting, typesetting, and review of the resulting proof before it is published in its final citable form. Please note that during the production process errors may be discovered which could affect the content, and all legal disclaimers that apply to the journal pertain.
} 
mouse strain carrying the HLA-A2.1 and CD11c-DTR genes. We then studied CD8 T-cell immune response against Tax(11-19) epitope delivered in the absence or presence of Freund's adjuvant and/or DCs. Overall results demonstrate that naturally presented Tax epitope could initiate an antigen-specific CD8 T cell response in vivo but failed to do so upon DC depletion. Presence of adjuvant potentiated Tax(11-19)-specific response. Elevated serum IL-6 levels coincided with depletion of DCs whereas decreased TGF- $\beta$ was associated with adjuvant use. Thus, $\operatorname{Tax}(11-19)$ epitope is a potential candidate for the DC-based anti-HTLV-1 vaccine and the newly hybrid mouse strain could be used for investigating DC involvement in human class-Irestricted immune responses.

\section{Keywords}

HTLV-1; Tax; dendritic cells; HLA-A2.1 transgenic mice; CD11c-DTR transgenic mice

\section{Introduction}

Human T-cell leukemia virus (HTLV-1) causes a spectrum of abnormalities, the most prominent being adult T-cell leukemia (ATL) and HTLV-1-associated myelopathy (HAM) [1]. Leukemic cells are usually monoclonal with respect to the integration of HTLV-1 provirus, which is the end result of progression from polyclonality during the course of Tcell transformation with the establishment of malignant cell lineages [2,3]. A number of epitopes of Tax, the major HTLV-1 oncogenic transactivator protein, have been recognized by HTLV-1-specific CD8 ${ }^{+}$CTLs in infected individuals carrying HLA-A2, -A11, or -A24 [4-10]. In HLA-A2 ${ }^{+}$patients, the frequency of Tax-specific CTLs can be as high as $30 \%$ of all CD8 ${ }^{+}$T-cells in the peripheral blood [11] and even higher in CSF[4, 12, 13], with Tax(11-19) epitope being the immunodominant epitope in both asymptomatic carriers [14], ATL [7, 15], and HAM [4, 6, 12, 16-19]. During the development of ATL, general immune suppression has been reportedly due to dysfunction of Tax-specific CTLs [7, 20]. In addition, both IFN- $\gamma$ production and proliferative capacity of tetramer-binding Tax-specific $\mathrm{CD}^{+}$T-cells are severely impaired in ATL patients [21], and a Tax-low or Tax-negative phenotype is associated with clonal proliferation of ATL cells [22, 23]. Consequently, it has been established that impairment of the Tax-specific response is critically involved in ATL induction and disease progression. ${ }^{1}$

ATL is highly aggressive and malignant with the median survival time measured in months even with standard treatment such as chemotherapy, antiviral drugs, or interferon therapy [24]. Autologous Tax-specific CTL therapy for primary ATL has shown promise leading to prolongation of survival time [25, 26]. Very recently, promising results from phase I clinical trials against ATL using Tax peptide-pulsed DC-based vaccination have been reported at the $16^{\text {th }}$ International Conference on Human Retrovirology, June 26-30, 2013, Montreal, Canada (Suehiro et al., abstract no. O1-2251). A significant reduction in proviral loads and size of lymph nodes with no severe side effects were observed in patients confirming a

\footnotetext{
${ }^{1}$ Abbreviations: AC, asymptomatic carrier; ATL, adult T-cell leukemia; CFSE, 5(6)-carboxyfluorescein diacetate N-succinimidyl ester; DC, dendritic cell; DT, diphtheria toxin; DTR, diphtheria toxin receptor; HAM/TSP, HTLV-1-associated myelopathy/tropical spastic paraparesis; HTLV-1, human T-cell leukemia virus type 1; IFA, incomplete freund's adjuvant; THP, tetanus helper peptide.
} 
therapeutic effect. Tax oligopeptide, particulary Tax(11-19), as a dominant CTL epitope can be harnessed to induce antitumor immunity, suggesting that it could be a suitable candidate for a DC-based vaccine against HTLV-1-induced ATL [27, 28]. Previously, we have shown that following exposure to Tax, murine and human DCs undergo activation and maturation, exhibit changes in activation markers, surface phenotype, and secretion of cytokines/ chemokines, leading to allogenic and Tax-specific immune responses [29-33]. We concluded that both Tax protein and its epitope (11-19) are potent enough to drive efficient antigen-specific CTL responses in naïve PBLs from normal donors as well as in HLA-A2.1 transgenic mice [34]. Hence, the promise of ATL therapy lies in reinstating a patient's antiHTLV-1 CTL response by developing DCs pulsed with the immunodominant epitope $\operatorname{Tax}(11-19)$ to facilitate recognition. In this respect, we [34] and others [35] have previously reported that Tax-pulsed DCs make highly potent immunostimulators; however, in vivo evidence has not been yet reported for the immunogenicity of the naturally identified HLAA*0201-restricted epitope 11-19 and the impact of DCs in this process.

DC priming in early stages of HTLV-1 infection has also been shown to be important for controlling disease progression [36]. To prove this, we had previously used a CD11cdiphtheria toxin receptor (DTR) transgenic mouse model $[37,38]$ that permits conditional transient depletion of CD11 $\mathrm{c}^{+} \mathrm{DCs}$. Infection of these mice was performed with chimeric HTLV-1 virus wherein the envelope gene of HTLV-1 was replaced with that of the ecotropic Moloney murine leukemia virus (Mo-MLV) for better fusion of envelope with murine cells [39] and better induction of humoral and cellular immune responses [40]. Upon both cell-free and cell-associated infection, we witnessed an increase and decrease in proviral load respectively, in both $\mathrm{CD}^{+}$and non $\mathrm{CD} 4^{+} \mathrm{T}$-cell fractions and significant reduction in IFN- $\gamma$ response in the $\mathrm{CD} 8^{+} \mathrm{T}$ cells. These results proved the importance of DCs in controlling cell-free virus and pointed toward the involvement of DCs in cellassociated infection. Here we wish to provide direct in vivo evidence for the importance of DCs with respect to in vivo immunogenicity of the HLA-A2-restricted Tax (11-19) epitope, which is immunodominant in both carriers of HTLV-1 and patients with the disease. To this end, C57BL/6-Tg (HLA-A2.1)1Enge/J male mice that express significant quantities of the human class I MHC Ag HLA-A2.1 were crossed with B6.FVB-Tg Itgax-DTR/EGFP 57Lan/J (CD11c-DTR) mice that express the simian DTR-enhanced green fluorescent protein (EGFP) under the control of the Itgax (or CD11c) promoter. The CD8 ${ }^{+} \mathrm{T}$-cell immune response in the newly hybrid HLA-A2.1/DTR transgenic mice were tested for both the naïve and a restimulation responses against Tax(11-19) antigen delivered with tetanus helper peptide (THP) in the absence or presence of adjuvant IFA (incomplete Freund's adjuvant; used as one experimental approach for immunogen delivery). In vivo depletion of CD11 $\mathrm{c}^{+}$DCs abrogated CD8 ${ }^{+} \mathrm{T}$-cell responses in the absence and presence of adjuvant, thereby implicating the initial priming of DCs with Tax(11-19) peptide in the successful generation of an efficient antigen-specific response. Depletion of DCs coincided with a much higher level of IL-6 in sera of mice that had not received IFA. This is the first report to our knowledge wherein a transgenic hybrid mouse model carrying HLA-A2.1 and DTR transgenes together was utilized for studying the $\mathrm{CD} 8^{+} \mathrm{T}$-cell immune response directed against a dominant HTLV-1 Tax(11-19) antigen. This in vivo model system could also 
facilitate future studies of DC-mediated HLA-A2-restricted antigen-specific immune responses.

\section{Results}

\section{Generation of novel transgenic hybrid mice containing HLA-A2.1/DTR transgenes}

Transgenic hybrid mice generated from an intercross between HLA-A2.1 and DTR transgenic mice were all healthy and viable. The presence of the HLA-A2.1 transgene (111 bp) was observed along with a control gene fragment (MGSCv37; Mouse Genome Sequencing Consortium for The Mus musculus strain C57BL/6J build 37) of $200 \mathrm{bp}$ and the DTR gene was detected by amplifying a 625-bp gene fragment (Fig. 1A, upper panel). The HLA-A2.1 transgene was found in 100\% of the F1 hybrid progeny and the DTR transgene was shown to be present in $49 \%$ of the hybrid progeny when 66 pups of the F1 generation were analyzed (52\% in females and $46 \%$ in males) (Fig. 1A, lower panel). These results were expected given the homozygous nature of HLA2.1 mice and the hemizygous nature of CD11c-DTR mice. Only double-positive mice were utilized in subsequent experiments.

\section{Depletion of CD11c ${ }^{+}$DCs in HLA-A2.1/DTR mice by the administration of diphtheria toxin}

The dose, timing, and route of DT administration were implemented as previously described [36]. In vivo depletion of conventional murine splenic DCs from hybrid mice were confirmed by assessing the frequency of $\mathrm{CD} 8 \mathrm{a}^{+} / \mathrm{CD} 11 \mathrm{c}^{+}$cells before and after DT treatment (Fig. 1B). As expected, most of the splenic DC population was ablated within $24 \mathrm{~h}$ of DT injection and was reduced to an average of $1.3 \%$ as compared with $5.5 \%$ of total CD8 ${ }^{+}$ splenocytes in the non-DT control group, as previously observed [36]. Similarly, the reduction in DC frequency slowly recovered by day 5 (data not shown), making it essential to complete the subsequent immunization studies within a 5-day interval. Since studies suggest the expression on CD11c on activated CD8 T cells [41, 42], we also determined the frequencies of $\mathrm{CD} 8 \mathrm{a}^{+} \mathrm{T}$ cells. It was found that $\mathrm{DT}$ administration did not affect either the frequency of $\mathrm{CD} 8 \mathrm{a}^{+} \mathrm{T}$ cells from which the $\mathrm{CD} 11 \mathrm{c}^{+}$cells were gated or $\mathrm{CD} 4^{+} \mathrm{T}$ cells (Supplementary Figure 1) which were also looked at.

\section{Depletion of DCs abrogated the immunogenicity of Tax(11-19)epitope}

In previous studies, we demonstrated the immunogenicity of Tax(11-19) epitope both in vitro and in vivo in line HHD II mice (expressing chimeric human and mouse HLA-A2.1 heavy chain linked to human 2-microglobulin) [34]. Here the impact of DC depletion on this process was examined in the newly hybrid strain. Levels of CFSE were first assessed on days 1 and 12 from splenocytes of control, nonimmunized mice stimulated in vitro with mitogen Con A (positive control), Tax(11-19) peptide, BMDCs, and BMDCs incubated with peptide. The twelve-day cultures were restimulated on day 5 to allow enough expansion of the anticipated low frequency of the antigen-specific cells. The average basal response of $\mathrm{CD}^{+} / \mathrm{CFSE}^{\mathrm{lo}}$ cells upon no stimulation in nonimmunized mice was $18.8 \%$. Con A stimulation showed $34.2 \%$ proliferation whereas with $\operatorname{Tax}(11-19)$ it was $46.2 \%$, with BMDCs $21 \%$, and with BMDCs $+\operatorname{Tax}(11-19) 14 \%$ (Fig. 2A). Thereafter, in vitro recall response in non-depleted and DC-depleted mice were calculated in this manner (Fig. 2B) as indicated by percentage of division or proliferation of $\mathrm{CD} 8^{+} \mathrm{T}$ cells. $\mathrm{CD} 8^{+}$splenocytes from 
non-DC-depleted immunized mice proliferated in response to Con A, as was observed with control mice, whereas those from DC-depleted mice exhibited a significantly reduced response. Stimulation with Tax peptide was also reduced significantly in the absence of DCs. Interestingly, stimulation of splenocytes with autologous BMDCs in the absence or presence of Tax peptide from non-DC-depleted mice exhibited a high degree of proliferation that was significantly hampered in cells from DC-depleted mice in both cases, which could be a combined effect of lack of splenic DCs as well as poor in vivo priming. There is a certain degree of proliferation that is still detected from DC-depleted mice, which could be attributed to residual DCs' presence ( 1\%, Figure 1B). It is noteworthy that stimulation with BMDCs + Tax(11-19) peptide showed higher proliferation of splenocytes when compared with BMDCs alone. Therefore, we sought to compare the ability of antigen-specific cells to respond in co-culture conditions in non-DC-depleted and depleted groups.

\section{Extent of Tax(11-19)-specific CD8 ${ }^{+}$T-cell response among total observed responses and the impact of DC depletion}

Once it was clear that immunization with Tax(11-19) peptide led to an efficient in vivo priming in HLA-A2.1/DTR mice, the specificity of this response was determined using PEconjugated Tax(11-19) pentamer that has been well characterized in our previous studies [36]. In addition, pentamer staining was used on control samples to validate the specificity as well as gating for the antigen-specific T-cells. The percentage of cells positive for Tax pentamer staining was obtained for each mouse by gating on total CD8 ${ }^{+} \mathrm{T}$-cells that showed low levels of CFSE at $24 \mathrm{~h}$ after co-culture (Fig. 3A). In non-DC-depleted mice, the frequency of pentamer-positive cells was $16 \%-66 \%$ out of the total $\mathrm{CD}^{+}$splenocytes. In DC-depleted mice, the frequency of antigen-specific cells was much lower (8\%-42\%). On day 12 of co-culture, antigen-specific $\mathrm{CD} 8^{+}$splenocytes were analyzed for their percentage of proliferation (Fig. 3A). In non-DC-depleted mice, 58\%-100\% of Tax(11-19)-specific $\mathrm{CD}^{+} \mathrm{T}$-cells divided in co-cultures (\% division) containing Tax peptide-loaded BMDCs (Fig. 3A \& B). As expected, administration of DT abrogated proliferation, and the resulting CFSE dilution into daughter $\mathrm{CD} 8^{+} \mathrm{T}$-cells was reduced to $13 \%-53 \%(\mathrm{P}<0.05)$ of $\operatorname{Tax}(11-19)$-specific CD8 ${ }^{+}$T-cells (Fig. 3A \& B).

\section{Adjuvant enhances immunogenicity of Tax(11-19) peptide via a DC-mediated mechanism}

IFA is a well-known adjuvant for enhancing innate immunity [43], inducing cytokine expression in regional lymph nodes [44], and opening the blood-brain barrier [45]. We checked immunogenic response of splenocytes to Tax(11-19) peptide in the presence and absence of IFA via the cytotoxic activity (Granzyme B), and pro-inflammatory cytokine secretion capacity (TNFa) (Supplementary Figure 2) in BMDC + Tax peptide co-culture. Interestingly, while TNFa was increased in both IFA and non-IFA groups, Granzyme B was detected in significantly higher levels in the IFA group only. We proceeded to determine the ability of this adjuvant to increase the $\mathrm{CD} 8^{+} \mathrm{T}$ cell responses of Tax antigen injected in HLA-A2.1/DTR transgenic hybrid mice. The impact of IFA administration in non-DCdepleted mice was examined for the frequency of Tax(11-19) pentamer-positive $\mathrm{CD}^{+} \mathrm{T}$ cells in the presence of IFA (49\%-67\%) (Fig. 4A) in the BMDC + Tax peptide co-culture. Out of these $\operatorname{Tax}(11-19)$ pentamer-positive cells, $36 \%-98 \%$ underwent proliferation as shown by the percent division (\% division) of CFSE-expressing cells. The percent frequency 
of Tax(11-19)-specific CD8 ${ }^{+}$T-cells was indeed mediated by DCs, as percent division by decreased to $2 \%-53 \%$ (Fig. 4A \& B) in the DC-depleted group.

To compare the effect of IFA versus non-IFA, the degree of proliferation [34] of total CD8 ${ }^{+}$ T-cells was examined. Number of generations was obtained by dividing the geometric mean fluorescence intensity (GMFI) of CFSE of the Day-0 peak by the GMFI of CFSE of each progressive peak so that the number of generations (n) = Day 0 GMFI/Day 12 GMFI. The mean number of generations on day 12 in response to BMDCs with the Tax peptide was $23.40 \pm 4.297$ (N=5, Fig. 5B) in mice that received IFA, in contrast to the high number of generations $(165.1 \pm 69.02)$ in non-IFA mice $(\mathrm{N}=5$, Fig. $5 \mathrm{~A})$. This was also true for splenocytes co-cultured with BMDCs alone $(13.86 \pm 1.836, \mathrm{~N}=5$, versus $98.90 \pm 33.97$, $\mathrm{N}=5$ ), whereas the controls, Con A and Tax peptide, did not show many differences in the absence or presence of IFA. DC depletion primarily affected the proliferation of total CD8 ${ }^{+}$ T-cells stimulated with BMDCs + Tax peptide in the absence and presence of IFA, but this was not significant as responses were highly variable within the non-DC-depleted groups (Fig. 5B). Furthermore, total $\mathrm{CD}^{+} \mathrm{T}$-cells showed significantly higher proliferation in the BMDC + Tax(11-19) peptide co-culture versus the BMDC co-culture in non-DC-depleted mice in the absence or presence of IFA. Overall, although antigen specificity was higher, proliferation was reduced upon adjuvant administration.

\section{Depletion of DCs leads to increased levels of serum IL-6}

The effect of DC depletion on the serum cytokine profile was determined by multiplexed cytokine analyses performed in immunized mice in the absence and presence of IFA. Shown in Figure 6A is a summary of the cumulative levels of all cytokines from serum pooled from five mice that were PBS-injected, Tax(11-19)-immunized, and Tax(11-19) + IFAimmunized. Out of the cytokines detected (Fig. 6B), IL-6, the Th17-associated cytokine, was strikingly high in animals that were DC-depleted. It has been shown previously that IL-6 signaling prevents the conversion of conventional T-cells into Foxp3-positive Tregs in vivo [46]. Such high levels of serum IL-6 could be secreted to control the number of Tregs in the absence of DCs. Similarly, IL-12, the Th1 cytokine, was moderately increased in DCdepleted mice versus nondepleted-mice in both nonadjuvant $(0.8 \mathrm{pg} / \mathrm{ml}$ versus undetected $)$ and adjuvant $(0.6 \mathrm{pg} / \mathrm{ml}$ versus $0.2 \mathrm{pg} / \mathrm{ml})$ groups, supporting the possibility that the presence of DCs is important to maintain tolerance during priming of T-cells.

A decrease of about two-fold in TGF- $\beta$ levels was observed in the adjuvant group as compared with the nonadjuvant group in both the absence $(8.8$ versus $19 \mathrm{pg} / \mathrm{ml})$ and presence ( 10 versus $17 \mathrm{pg} / \mathrm{ml}$ ) of DCs. TGF- $\beta$ is known to be involved in maintenance of tolerance in the periphery [47-49]. The reduction in the level of this cytokine in IFA-treated mice may be associated with inducing a more robust frequency of Tax-specific T-cells, as observed in Figure 5. Another cytokine detected was IL-17A, a Th17 cytokine, which was induced (from an undetectable level to $0.8 \mathrm{pg} / \mathrm{ml}$ ) upon adjuvant administration in the presence of DCs. 


\section{Discussion}

The role of DCs with respect to HTLV-1 pathogenesis in general and the Tax-specific CTL response in particular have been previously characterized [34]. Based on available clinical data, the majority of the class I epitopes identified has been predicted to belong to either the HLA-A2 or HLA-A24 haplotype [7][50]. Most HTLV-1-infected subjects carrying the HLA-A2 haplotype were found to be either A*0201 or A*0206, and nearly all HLA-A24 subjects were $A * 2402[50,51]$. Consequently, we proceeded to determine whether immunization with Tax(11-19), the HLA-A2 restricted immunodominant epitope, was DCdependent in vivo and whether Tax(11-19)-specific CTL expansion could be facilitated using autologous DCs upon restimulation with Tax antigen.

A DTR-based transgenic system that allowed the inducible in vivo ablation of DCs was thus used [38]. Furthermore, because the available CD11c-DTR mice are unable to present HLAA2.1-specific antigens, they were crossbred with HLA-A2.1-transgenic mice. The homozygous mice carrying the HLA-A2.1 transgene (obtained from hemizygous mating) were crossbred with homozygous mice carrying the DTR transgene (obtained from a hemizygous $\times$ inbred mating). Hence, all F1 progeny showed HLA-A2.1 transgene expression, about half of which (49\%) also contained the DTR transgene (Fig. 1A). Subsequently, a colony of mice positive for both HLA-A2.1 and DTR transgenes was maintained with depletion of splenic DCs achieved using a previously defined dose of DT [36] (Fig. 1B). A successful recall response to Tax(11-19) was observed in terms of the in vitro proliferation of $\mathrm{CD} 8^{+} \mathrm{T}$-cells in control non-DC-depleted mice, whereas depletion of DCs exhibited poor or no response (Fig. 2). The observed response was specific to the antigen examined and was enhanced by the presence of adjuvant (IFA) but required the presence of DCs in vivo (Fig. 3 and 4). However, the degree of proliferation was lower in the adjuvant group as compared with the nonadjuvant group (Fig. 5). Such decreases have been reported previously under certain circumstances upon administration of IFA indicating that it induces a more controlled antigen-specific induction of disease [52-59].

These results suggest that effective DC-dependent immunotherapy can be generated by immunization with the immunodominant Tax(11-19) antigen along with adjuvant in HTLV-1-infected patients. Other epitopes including Tax [185-193], Envgp46 [247-255, 247-256, 247-257, 249-257, and 257-265] and Pol [177-185 and 177-187], restricted to HLA-B35, are also known to be recognized by HTLV-specific CTLs in vivo [60]. Epitopes associated with HLA-A3 and HLA-B14 could also be of interest while considering antiATL DC therapy [61]. Reports summarizing the panel of HLA-A2.1-Tax(11-19) reactive Tcell clones indicate that small allelic variations of MHC molecules could alter the functional outcome of antigen recognition [62]. In HAM/TSP, the present findings indicate that MHC class I-restricted CTLs reduce the proviral load of HTLV-1 and consequently increase the risk of HAM/TSP [63]. The DRB1*0101 HLA allele predisposes an individual to HAM/TSP in the absence of $\mathrm{A}^{*} 0201$, which would usually play a protective role in the $\mathrm{CD} 8^{+}$-mediated immune response. Therefore, the ability to engineer DC-based vaccine therapies against appropriate antigen-specific response may enable us to overcome this dysfunction thereby enhancing immunogenicity or tolerance in ATL and HAM/TSP patients, respectively. 


\section{Conclusion}

Our goal for elucidating the importance of DCs in presentation of Tax to naïve CD8 ${ }^{+} \mathrm{T}$-cells as the basis for induction of a Tax-specific CTL response continues as we report here that the clinically characterized epitope (11-19) of Tax can initiate a CD8 ${ }^{+} \mathrm{T}$ cell-mediated response in vivo but failed to do so upon DC depletion, showing the importance of Tax(11-19) in priming of DCs against HTLV-1 infection. Thus, these studies have provided data that support the development of a novel candidate vaccine directed against HTLV-1 infection and a transgenic hybrid mouse strain that may be useful in other investigations into human immune responses.

\section{Materials and Methods}

\section{Generation of transgenic hybrid mice and genotyping}

Male C57BL/6-Tg(HLA-A2.1)1Enge/J mice carrying the HLA-A2.1 transgene in spleen, $\mathrm{BM}$, and thymus [64] and age-matched female B6.FVB-Tg Itgax-DTR/EGFP 57Lan/J (CD11c-DTR) mice carrying the DTR-EGFP transgene under the control of the CD11c promoter [38] were purchased from The Jackson Laboratory (Bar Harbor, ME) and bred as recommended by the supplier. The animals were maintained in the housing facility of Lampire Biological Laboratories (Ottsville, PA). All animal experiments were conducted under the protocol approved by the Institutional Animal Care and Use Committee (IACUC) of both Lampire Biological Laboratories and Drexel University College of Medicine. We obtained informed consent from the supplier to cross-breed the two strains. The pups were genotyped by PCR using DNA obtained from tail clippings as previously described by The Jackson Laboratory. Specific primer sequences (Integrated Device Technology, San Jose, CA) used for genotyping included an internal control MGSCv37: F/R (5'-3') CAAATGTTGCTTGTCTGGTG/GTCAGTCGAGTGCACGTTT, HLA-A2.1: TTCTCCCTCT CCCAACCTATGTAG/CGACGACACTGATTGGCTTCT, and DTR: GGGACCATGAA GCTGCTGCG/TCAGTGGGAATTAGTCATGCC. For all experiments double-positive mice carrying both the HLA-A2.1 and DTR genes were utilized.

\section{Confirmation of DC depletion in HLA-A2.1/DTR transgenic mice}

DT was purchased from Sigma-Aldrich (St. Louis, MO) and DC depletion was confirmed in newly hybrid mice as previously described [36]. Six- to 10-week-old mice (M:F ratio 2:3) were given (i.p.) either PBS as control or a uniform dose of DT (a total of $100 \mathrm{ng}$ per animal or $\sim 5 \mathrm{ng} / \mathrm{g}$ body weight of mouse). Spleens were harvested after $24 \mathrm{~h}$ from control (-DT) and DT-administered (+DT) groups and stained with FITC-conjugated anti-CD4 marker, PE-conjugated mouse anti-CD11c and APC-conjugated mouse anti-CD8a. A minimum of 50,000 events were acquired using a FACSCalibur (BD Biosciences, San Jose, CA) and analyzed using FlowJo software (Tree Star, Ashland, OR). Live cells were gated to include conventional murine splenic DCs $\left(\mathrm{CD} 11 \mathrm{c}^{+} / \mathrm{CD} 8 \mathrm{a}^{+}\right)$and plotted as double-positive cells for five mice from each group. The same number of mice was used in all subsequent studies. 


\section{Immunization of HLA-A2.1/DTR transgenic mice}

Twenty-four hours prior to immunization, animals were injected with either PBS or DT as described above. In vivo priming was performed by immunizing mice with $100 \mu \mathrm{g}$ of synthetic 11-19 peptide (LLFGYPVYV, Alpha Diagnostics, San Antonio, TX) in conjunction with $50 \mu \mathrm{g}$ THP (LQTMVKLFNRIKNNVA) in a total volume of $100 \mu \mathrm{l}$ through both i.d. $(50 \mu \mathrm{l})$ and s.c. $(50 \mu \mathrm{l})$ routes. In adjuvant studies, Tax peptide was emulsified in IFA (Sigma). Within 5 days, both spleen and bones were harvested and processed as previously described [36] from each mouse. Cells were cultured for 8 days with $20 \%$ murine Fms-like tyrosine kinase 3 ligand-containing supernatant obtained from an SP2/0 transfected cell line [65]. BMDCs were harvested and examined for purity using a PE-conjugated anti-CD11c antibody (eBioscience, San Diego, CA) using flow cytometry.

\section{Effect of DC depletion on the in vivo immunogenicity of Tax(11-19)epitope}

BMDCs were used alone or stimulated with Tax peptide $(100 \mathrm{nM})$ for $1 \mathrm{~h}$ at $37^{\circ} \mathrm{C}$ and cocultured (1:1) with corresponding splenocytes labeled with CFSE (Sigma). On day 5, the coculture was supplied with restimulated autologous BMDCs. Controls were set up in parallel by directly stimulating labeled splenocytes with Con A, $1 \mu \mathrm{g}$ (Sigma), or Tax peptide alone. All cultures were harvested on days 0, 1, and 12 and stained with APC-conjugated antimouse CD8 antibody (eBioscience). Supernatant was collected from co-cultures at Day 12 and cytokine secretion was measured using the MILLIPLEX magnetic bead assay according to manufacturer's instructions (Millipore, Billerica, MA). Proliferation of total CD8 ${ }^{+}$T-cells was determined by the level of CFSE dilution. Percentage of division (\% Division) was obtained by using the "Proliferation" function using the FlowJo 8.8.6 software. A baseline of undivided cell population for each experimental sample was set to calculate this proliferation function. This baseline is indicated in the histograms as gates for the relevant figures. To examine an antigen-specific immune response, cells were stained with PEconjugated Tax(11-19) pentamer (ProImmune, Sarasota, FL) and analyzed using flow cytometry as described above. Where necessary, the number of generations was calculated [34] on the basis of reduction in the CFSE fluorescence by using the formula: number of generation $(\mathrm{n})=$ geometric mean fluorescence intensity at day $0 /$ geometric mean fluorescence intensity at day 12 .

\section{Detection of serum cytokines}

Serum samples from each group were analyzed for cytokines using the mouse Multi-Analyte ELISA Array procedure as described by the manufacturer (Qiagen, Germantown, MD). This assay included Th1 cytokines IL-2, IL-10, IL-12, IFN- $\gamma$, and TNF- $\alpha$; Th2 cytokines IL-2, IL-4, IL-5, IL-10, and IL-13; and Th17 cytokines IL-6, IL-17A, IL-23, TNF-a, and TGF- $\beta$. Undiluted serum $(50 \mu \mathrm{l})$ from each sample or standard was added and incubated for $2 \mathrm{~h}$ at room temperature. Plates were washed and incubated with detection antibody followed by avidin-HRP solution, and absorbance was read at $450 \mathrm{~nm}$ using the Rainbow Microplate reader (Tecan Group, Ltd., Männedorf, Switzerland). Cytokine concentrations were determined from the respective standard curve and represented as $\mathrm{pg} / \mathrm{ml}$. 


\section{Supplementary Material}

Refer to Web version on PubMed Central for supplementary material.

\section{Acknowledgments}

This work was supported by the Public Health Service, National Institutes of Health, grant NIAID R21 AI093172-01 to ZKK. Supports through NIAID R01 AI077414 to PJ and NCI R01 to BW/PJ are also acknowledged. We also wish to acknowledge the kind gift of SP2/0 transfectants secreting mouse recombinant Flt-3L from Dr. Robert Rottapel, Ontario Cancer Institute, Toronto, Canada. Both strains of mice were purchased from Jackson Laboratories, which helped in obtaining permission to cross-breed from the original source of these mice and requested acknowledgment of Dr. Dan Littman for B6.FVB-Tg Itgax-DTR/EGFP 57Lan/J (CD11c-DTR) mice.

\section{References}

1. Uchiyama T. Human T cell leukemia virus type I (HTLV-I) and human diseases. Annu Rev Immunol. 1997; 15:15-37. [PubMed: 9143680]

2. Amano M, Setoyama M, Grant A, Kerdel FA. Human T-lymphotropic virus 1 (HTLV-1) infection-dermatological implications. Int J Dermatol. 2011 Aug; 50(8):915-20. [PubMed: 21781059]

3. Franchini G. Molecular mechanisms of human T-cell leukemia/lymphotropic virus type I infection. Blood. 1995 Nov 15; 86(10):3619-39. [PubMed: 7579327]

4. Elovaara I, Koenig S, Brewah AY, Woods RM, Lehky T, Jacobson S. High human T cell lymphotropic virus type 1 (HTLV-1)-specific precursor cytotoxic T lymphocyte frequencies in patients with HTLV-1-associated neurological disease. J Exp Med. 1993 Jun 1; 177(6):1567-73. [PubMed: 8496677]

5. Harashima N, Tanosaki R, Shimizu Y, Kurihara K, Masuda T, Okamura J, et al. Identification of two new HLA-A*1101-restricted tax epitopes recognized by cytotoxic T lymphocytes in an adult Tcell leukemia patient after hematopoietic stem cell transplantation. J Virol. 2005 Aug; 79(15): 10088-92. [PubMed: 16014972]

6. Kannagi M, Shida H, Igarashi H, Kuruma K, Murai H, Aono Y, et al. Target epitope in the Tax protein of human T-cell leukemia virus type I recognized by class I major histocompatibility complex-restricted cytotoxic T cells. J Virol. 1992 May; 66(5):2928-33. [PubMed: 1373197]

7. Kozako T, Arima N, Toji S, Masamoto I, Akimoto M, Hamada H, et al. Reduced frequency, diversity, and function of human $\mathrm{T}$ cell leukemia virus type 1-specific CD8+ T cell in adult $\mathrm{T}$ cell leukemia patients. J Immunol. 2006 Oct 15; 177(8):5718-26. [PubMed: 17015761]

8. Kubota R, Soldan SS, Martin R, Jacobson S. An altered peptide ligand antagonizes antigen-specific $\mathrm{T}$ cells of patients with human T lymphotropic virus type I-associated neurological disease. J Immunol. 2000 May 15; 164(10):5192-8. [PubMed: 10799878]

9. Kurihara K, Harashima N, Hanabuchi S, Masuda M, Utsunomiya A, Tanosaki R, et al. Potential immunogenicity of adult T cell leukemia cells in vivo. Int J Cancer. 2005 Mar 20; 114(2):257-67. [PubMed: 15551352]

10. Lee L, Loftus D, Appella E, Margulies DH, Mage M. A recombinant single-chain HLA-A2.1 molecule, with a cis active beta-2-microglobulin domain, is biologically active in peptide binding and antigen presentation. Hum Immunol. 1996 Aug; 49(1):28-37. [PubMed: 8839773]

11. Yamano Y, Nagai M, Brennan M, Mora CA, Soldan SS, Tomaru U, et al. Correlation of human Tcell lymphotropic virus type 1 (HTLV-1) mRNA with proviral DNA load, virus-specific CD8(+) T cells, and disease severity in HTLV-1-associated myelopathy (HAM/TSP). Blood. 2002 Jan 1; 99(1):88-94. [PubMed: 11756157]

12. Greten TF, Slansky JE, Kubota R, Soldan SS, Jaffee EM, Leist TP, et al. Direct visualization of antigen-specific T cells: HTLV-1 Tax11-19- specific CD8(+) T cells are activated in peripheral blood and accumulate in cerebrospinal fluid from HAM/TSP patients. Proc Natl Acad Sci U S A. 1998 Jun 23; 95(13):7568-73. [PubMed: 9636190] 
13. Nagai M, Yamano Y, Brennan MB, Mora CA, Jacobson S. Increased HTLV-I proviral load and preferential expansion of HTLV-I Tax-specific CD8+ T cells in cerebrospinal fluid from patients with HAM/TSP. Ann Neurol. 2001 Dec; 50(6):807-12. [PubMed: 11761481]

14. Best I, Lopez G, Verdonck K, Gonzalez E, Tipismana M, Gotuzzo E, et al. IFN-gamma production in response to Tax 161-233, and frequency of CD4+ Foxp3+ and Lin HLA-DRhigh CD123+ cells, discriminate HAM/TSP patients from asymptomatic HTLV-1-carriers in a Peruvian population. Immunology. 2009 Sep; 128(1 Suppl):e777-86. [PubMed: 19740339]

15. Kurihara K, Shimizu Y, Takamori A, Harashima N, Noji M, Masuda T, et al. Human T-cell leukemia virus type-I (HTLV-I)-specific T-cell responses detected using three-divided glutathione-S-transferase (GST)-Tax fusion proteins. J Immunol Methods. 2006 Jun 30; 313(1-2): 61-73. [PubMed: 16723135]

16. Parker KC, Bednarek MA, Coligan JE. Scheme for ranking potential HLA-A2 binding peptides based on independent binding of individual peptide side-chains. J Immunol. 1994 Jan 1; 152(1): 163-75. [PubMed: 8254189]

17. Bieganowska K, Hollsberg P, Buckle GJ, Lim DG, Greten TF, Schneck J, et al. Direct analysis of viral-specific CD8+ T cells with soluble HLA-A2/Tax11-19 tetramer complexes in patients with human T cell lymphotropic virus-associated myelopathy. J Immunol. 1999 Feb 1; 162(3):1765-71. [PubMed: 9973440]

18. Tomaru U, Yamano Y, Nagai M, Maric D, Kaumaya PT, Biddison W, et al. Detection of virusspecific T cells and CD8+ T-cell epitopes by acquisition of peptide-HLA-GFP complexes: analysis of T-cell phenotype and function in chronic viral infections. Nat Med. 2003 Apr; 9(4): 469-76. [PubMed: 12652294]

19. Kattan T, MacNamara A, Rowan AG, Nose H, Mosley AJ, Tanaka Y, et al. The avidity and lytic efficiency of the CTL response to HTLV-1. J Immunol. 2009 May 1; 182(9):5723-9. [PubMed: 19380819]

20. Arnulf B, Thorel M, Poirot Y, Tamouza R, Boulanger E, Jaccard A, et al. Loss of the ex vivo but not the reinducible CD8+ T-cell response to Tax in human T-cell leukemia virus type 1-infected patients with adult T-cell leukemia/lymphoma. Leukemia. 2004 Jan; 18(1):126-32. [PubMed: 14574331]

21. Takamori A, Hasegawa A, Utsunomiya A, Maeda Y, Yamano Y, Masuda M, et al. Functional impairment of Tax-specific but not cytomegalovirus-specific CD8+ T lymphocytes in a minor population of asymptomatic human T-cell leukemia virus type 1-carriers. Retrovirology. 2011; 8:100. [PubMed: 22151736]

22. Koiwa T, Hamano-Usami A, Ishida T, Okayama A, Yamaguchi K, Kamihira S, et al. 5'-long terminal repeat-selective $\mathrm{CpG}$ methylation of latent human T-cell leukemia virus type 1 provirus in vitro and in vivo. J Virol. 2002 Sep; 76(18):9389-97. [PubMed: 12186921]

23. Tamiya S, Matsuoka M, Etoh K, Watanabe T, Kamihira S, Yamaguchi K, et al. Two types of defective human T-lymphotropic virus type I provirus in adult T-cell leukemia. Blood. 1996 Oct 15; 88(8):3065-73. [PubMed: 8874205]

24. Marcais A, Suarez F, Sibon D, Frenzel L, Hermine O, Bazarbachi A. Therapeutic options for adult T-cell leukemia/lymphoma. Curr Oncol Rep. Oct; 15(5):457-64. [PubMed: 23943384]

25. Masaki A, Ishida T, Suzuki S, Ito A, Mori F, Sato F, et al. Autologous Tax-Specific CTL Therapy in a Primary Adult T Cell Leukemia/Lymphoma Cell-Bearing NOD/Shi-scid, IL-2Rgammanull Mouse Model. J Immunol. 2013 Jul 1; 191(1):135-44. [PubMed: 23733874]

26. Tamai Y, Hasegawa A, Takamori A, Sasada A, Tanosaki R, Choi I, et al. Potential contribution of a novel Tax epitope-specific CD4+ T cells to graft-versus-Tax effect in adult T cell leukemia patients after allogeneic hematopoietic stem cell transplantation. J Immunol. 2013 Apr 15; 190(8): 4382-92. [PubMed: 23475215]

27. Hanabuchi S, Ohashi T, Koya Y, Kato H, Hasegawa A, Takemura F, et al. Regression of human Tcell leukemia virus type I (HTLV-I)-associated lymphomas in a rat model: peptide-induced T-cell immunity. J Natl Cancer Inst. 2001 Dec 5; 93(23):1775-83. [PubMed: 11734593]

28. Ohashi T, Hanabuchi S, Kato H, Tateno H, Takemura F, Tsukahara T, et al. Prevention of adult Tcell leukemia-like lymphoproliferative disease in rats by adoptively transferred $\mathrm{T}$ cells from a donor immunized with human T-cell leukemia virus type 1 Tax-coding DNA vaccine. J Virol. 2000 Oct; 74(20):9610-6. [PubMed: 11000233] 
29. Ahuja J, Kampani K, Datta S, Wigdahl B, Flaig KE, Jain P. Use of human antigen presenting cell gene array profiling to examine the effect of human T-cell leukemia virus type 1 Tax on primary human dendritic cells. J Neurovirol. 2006 Feb; 12(1):47-59. [PubMed: 16595374]

30. Ahuja J, Lepoutre V, Wigdahl B, Khan ZK, Jain P. Induction of pro-inflammatory cytokines by human T-cell leukemia virus type-1 Tax protein as determined by multiplexed cytokine protein array analyses of human dendritic cells. Biomed Pharmacother. 2007 May; 61(4):201-8. [PubMed: 17391906]

31. Jain P, Ahuja J, Khan ZK, Shimizu S, Meucci O, Jennings SR, et al. Modulation of dendritic cell maturation and function by the Tax protein of human T cell leukemia virus type 1. J Leukoc Biol. 2007 Jul; 82(1):44-56. [PubMed: 17442856]

32. Mostoller K, Norbury CC, Jain P, Wigdahl B. Human T-cell leukemia virus type I Tax induces the expression of dendritic cell markers associated with maturation and activation. J Neurovirol. 2004 Dec; 10(6):358-71. [PubMed: 15765807]

33. Rahman S, Khan ZK, Wigdahl B, Jennings SR, Tangy F, Jain P. Murine FLT3 ligand-derived dendritic cell-mediated early immune responses are critical to controlling cell-free human $\mathrm{T}$ cell leukemia virus type 1 infection. J Immunol. Jan 1; 186(1):390-402. [PubMed: 21115731]

34. Manuel SL, Schell TD, Acheampong E, Rahman S, Khan ZK, Jain P. Presentation of human T cell leukemia virus type 1 (HTLV-1) Tax protein by dendritic cells: the underlying mechanism of HTLV-1-associated neuroinflammatory disease. J Leukoc Biol. 2009 Nov; 86(5):1205-16. [PubMed: 19656902]

35. Peshwa MV, Page LA, Qian L, Yang D, van Schooten WC. Generation and ex vivo expansion of HTLV-1 specific CD8+ cytotoxic T-lymphocytes for adoptive immunotherapy. Biotechnol Bioeng. 1996 Jun 5; 50(5):529-40. [PubMed: 18627015]

36. Rahman S, Manuel SL, Khan ZK, Wigdahl B, Acheampong E, Tangy F, et al. Depletion of dendritic cells enhances susceptibility to cell-free infection of human T cell leukemia virus type 1 in CD11c-diphtheria toxin receptor transgenic mice. J Immunol. 2010 May 15; 184(10):5553-61. [PubMed: 20382884]

37. Brocker T, Riedinger M, Karjalainen K. Targeted expression of major histocompatibility complex (MHC) class II molecules demonstrates that dendritic cells can induce negative but not positive selection of thymocytes in vivo. J Exp Med. 1997 Feb 3; 185(3):541-50. [PubMed: 9053454]

38. Jung S, Unutmaz D, Wong P, Sano G, De los Santos K, Sparwasser T, et al. In vivo depletion of $\mathrm{CD} 11 \mathrm{c}+$ dendritic cells abrogates priming of CD8+ T cells by exogenous cell-associated antigens. Immunity. 2002 Aug; 17(2):211-20. [PubMed: 12196292]

39. Delebecque F, Pramberger K, Prevost MC, Brahic M, Tangy F. A chimeric human T-cell lymphotropic virus type 1 with the envelope glycoprotein of Moloney murine leukemia virus is infectious for murine cells. J Virol. 2002 Aug; 76(15):7883-9. [PubMed: 12097602]

40. Delebecque F, Combredet C, Gabet AS, Wattel E, Brahic M, Tangy F. A chimeric human T cell leukemia virus type I bearing a deltaR Moloney-murine leukemia virus envelope infects mice persistently and induces humoral and cellular immune responses. J Infect Dis. 2005 Jan 15; 191(2):255-63. [PubMed: 15609236]

41. Huleatt JW, Lefrancois L. Antigen-driven induction of CD11c on intestinal intraepithelial lymphocytes and CD8+ T cells in vivo. J Immunol. 1995 Jun 1; 154(11):5684-93. [PubMed: 7751620]

42. Lin Y, Roberts TJ, Sriram V, Cho S, Brutkiewicz RR. Myeloid marker expression on antiviral CD8+ T cells following an acute virus infection. Eur J Immunol. 2003 Oct; 33(10):2736-43. [PubMed: 14515257]

43. Castro AP, Aguas AP, Silva MT. Adjuvant treatment increases the resistance to Mycobacterium avium infection of mycobacteria-susceptible BALB/c mice. Clin Exp Immunol. 1993 Jun; 92(3): 466-72. [PubMed: 8513578]

44. Mussener A, Klareskog L, Lorentzen JC, Kleinau S. TNF-alpha dominates cytokine mRNA expression in lymphoid tissues of rats developing collagen- and oil-induced arthritis. Scand J Immunol. 1995 Jul; 42(1):128-34. [PubMed: 7631134] 
45. Rabchevsky AG, Degos JD, Dreyfus PA. Peripheral injections of Freund's adjuvant in mice provoke leakage of serum proteins through the blood-brain barrier without inducing reactive gliosis. Brain Res. 1999 Jun 19; 832(1-2):84-96. [PubMed: 10375654]

46. Korn T, Mitsdoerffer M, Croxford AL, Awasthi A, Dardalhon VA, Galileos G, et al. IL-6 controls Th17 immunity in vivo by inhibiting the conversion of conventional T cells into Foxp3+ regulatory T cells. Proc Natl Acad Sci U S A. 2008 Nov 25; 105(47):18460-5. [PubMed: 19015529]

47. Fantini MC, Becker C, Monteleone G, Pallone F, Galle PR, Neurath MF. Cutting edge: TGF-beta induces a regulatory phenotype in CD4+CD25- T cells through Foxp3 induction and downregulation of Smad7. J Immunol. 2004 May 1; 172(9):5149-53. [PubMed: 15100250]

48. Tran DQ, Ramsey H, Shevach EM. Induction of FOXP3 expression in naive human CD4+FOXP3 $\mathrm{T}$ cells by T-cell receptor stimulation is transforming growth factor-beta dependent but does not confer a regulatory phenotype. Blood. 2007 Oct 15; 110(8):2983-90. [PubMed: 17644734]

49. Marie JC, Liggitt D, Rudensky AY. Cellular mechanisms of fatal early-onset autoimmunity in mice with the T cell-specific targeting of transforming growth factor-beta receptor. Immunity. 2006 Sep; 25(3):441-54. [PubMed: 16973387]

50. Kozako T, Akimoto M, Toji S, White Y, Suzuki S, Arima T, et al. Target epitopes of HTLV-1 recognized by class I MHC-restricted cytotoxic T lymphocytes in patients with myelopathy and spastic paraparesis and infected patients with autoimmune disorders. J Med Virol. 2011 Mar; 83(3):501-9. [PubMed: 21264872]

51. Sonoda S, Fujiyoshi T, Yashiki S, Li HC, Lou H, Lema C. Genetic diversity of HLA in HTLV-I infection. Uirusu. 2000 Jun; 50(1):37-45. [PubMed: 10998977]

52. Marusic S, Tonegawa S. Tolerance induction and autoimmune encephalomyelitis amelioration after administration of myelin basic protein-derived peptide. J Exp Med. 1997 Aug 18; 186(4): 507-15. [PubMed: 9254649]

53. Jagessar SA, Heijmans N, Blezer EL, Bauer J, Blokhuis JH, Wubben JA, et al. Unravelling the Tcell-mediated autoimmune attack on CNS myelin in a new primate EAE model induced with MOG34-56 peptide in incomplete adjuvant. Eur J Immunol. 2012 Jan; 42(1):217-27. [PubMed: 21928277]

54. Zamora A, Matejuk A, Silverman M, Vandenbark AA, Offner H. Inhibitory effects of incomplete Freund's adjuvant on experimental autoimmune encephalomyelitis. Autoimmunity. 2002 Feb; 35(1):21-8. [PubMed: 11908703]

55. Clayton JP, Gammon GM, Ando DG, Kono DH, Hood L, Sercarz EE. Peptide-specific prevention of experimental allergic encephalomyelitis. Neonatal tolerance induced to the dominant $\mathrm{T}$ cell determinant of myelin basic protein. J Exp Med. 1989 May 1; 169(5):1681-91. [PubMed: 2469764]

56. Gammon GM, Oki A, Shastri N, Sercarz EE. Induction of tolerance to one determinant on a synthetic peptide does not affect the response to a second linked determinant. Implications for the mechanism of neonatal tolerance induction. J Exp Med. 1986 Aug 1; 164(2):667-72. [PubMed: 2425038]

57. Kearney ER, Pape KA, Loh DY, Jenkins MK. Visualization of peptide-specific T cell immunity and peripheral tolerance induction in vivo. Immunity. 1994 Jul; 1(4):327-39. [PubMed: 7889419]

58. Billiau A, Matthys P. Modes of action of Freund's adjuvants in experimental models of autoimmune diseases. J Leukoc Biol. 2001 Dec; 70(6):849-60. [PubMed: 11739546]

59. Heeger PS, Forsthuber T, Shive C, Biekert E, Genain C, Hofstetter HH, et al. Revisiting tolerance induced by autoantigen in incomplete Freund's adjuvant. J Immunol. 2000 Jun 1; 164(11):577181. [PubMed: 10820255]

60. Schonbach C, Miwa K, Ibe M, Shiga H, Nokihara K, Takiguchi M. Refined peptide HLA-B*3501 binding motif reveals differences in 9-mer to 11-mer peptide binding. Immunogenetics. 1996; 45(2):121-9. [PubMed: 8952961]

61. Koenig S, Woods RM, Brewah YA, Newell AJ, Jones GM, Boone E, et al. Characterization of MHC class I restricted cytotoxic T cell responses to tax in HTLV-1 infected patients with neurologic disease. J Immunol. 1993 Oct 1; 151(7):3874-83. [PubMed: 7690819] 
62. Lim DG, Slavik JM, Bourcier K, Smith KJ, Hafler DA. Allelic variation of MHC structure alters peptide ligands to induce atypical partial agonistic CD8+ T cell function. J Exp Med. 2003 Jul 7; 198(1):99-109. [PubMed: 12847139]

63. Jeffery KJ, Usuku K, Hall SE, Matsumoto W, Taylor GP, Procter J, et al. HLA alleles determine human T-lymphotropic virus-I (HTLV-I) proviral load and the risk of HTLV-I-associated myelopathy. Proc Natl Acad Sci U S A. 1999 Mar 30; 96(7):3848-53. [PubMed: 10097126]

64. Le AX, Bernhard EJ, Holterman MJ, Strub S, Parham P, Lacy E, et al. Cytotoxic T cell responses in HLA-A2.1 transgenic mice. Recognition of HLA alloantigens and utilization of HLA-A2.1 as a restriction element. J Immunol. 1989 Feb 15; 142(4):1366-71. [PubMed: 2464645]

65. Dehlin M, Bokarewa M, Rottapel R, Foster SJ, Magnusson M, Dahlberg LE, et al. Intra-articular fms-like tyrosine kinase 3 ligand expression is a driving force in induction and progression of arthritis. PLoS One. 2008; 3(11):e3633. [PubMed: 18982072] 


\section{Highlights}

- HLA-A2/DTR transgenic mouse strain was generated to study immunogenicity of Tax 11-19 epitope.

- A reduced proliferation of CD8+ splenocytes from Tax 11-19 immunized DCdepleted mice is observed.

- Adjuvant usage demonstrated higher frequency of Tax 11-19-specific cells.

- Tax 11-19 epitope can be a potential candidate for a DC-based anti-HTLV-1 vaccine. 
A
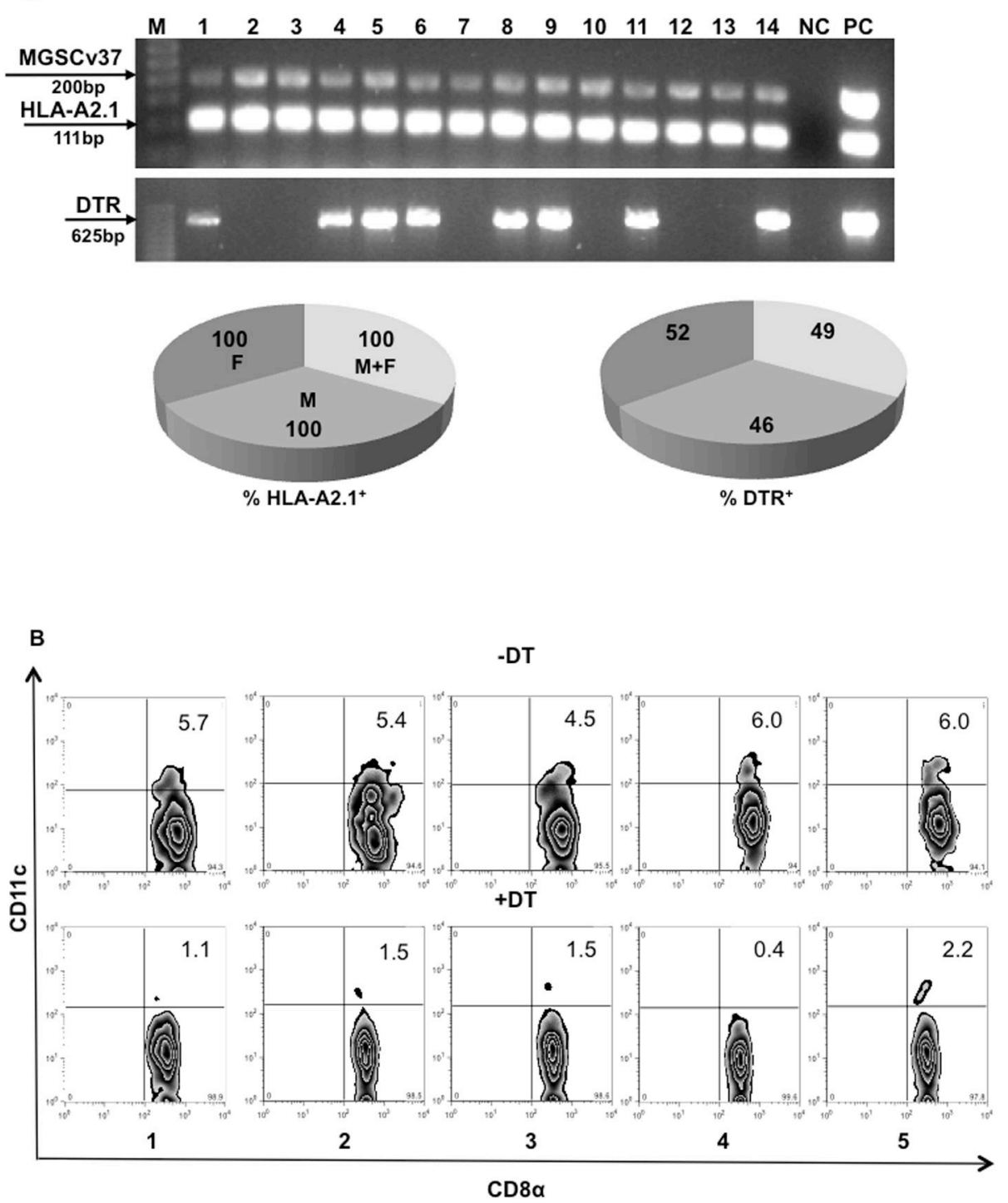

Figure 1. Genotyping mice to confirm presence of HLA-A2.1 and DTR transgenes and verification of splenic $D C$-depletion

Male C57BL/6-Tg (HLA-A2.1)1Enge/J mice carrying human MHC class I antigen HLAA2.1 and age-matched female B6.FVB-Tg Itgax-DTR/EGFP 57Lan/J (DTR) mice were bred as described by standard guidelines provided by the supplier. The genotype of the pups was determined by PCR using tail DNA and specific primers for a control gene fragment, MGSCv37 (Mouse Genome Sequencing Consortium version 37, the most recent version of the C57BL/6J mouse genome assembly), HLA-A2.1, and DTR genes. A) Upper panel, representative data from 14 pups. $\mathrm{M}$ represents the DNA molecular weight marker, 1-14 indicates number of pups, $\mathrm{NC}$ denotes negative primer control, and $\mathrm{PC}$ denotes positive control DNA provided by the supplier. Lower panel, percentage and distribution of transgenes in females $(\mathrm{F})$ and males $(\mathrm{M})$ derived from 66 pups of $\mathrm{F} 1$ generation. Mice were given (i.p.) either PBS as the control or a uniform dose of $100 \mathrm{ng}$ DT. B) Splenocytes were harvested and stained for CD11c and CD8a markers, gated for CD8 ${ }^{+}$T-cells and further 
plotted as $\mathrm{CD} 11 \mathrm{c}^{+} / \mathrm{CD} 8 \mathrm{a}^{+}$murine splenic DCs. Data shown are for $-\mathrm{DT}$ and $+\mathrm{DT}$ groups 24 $\mathrm{h}$ after DT administration. Number 1-5 represents mice from each group. 
A
2
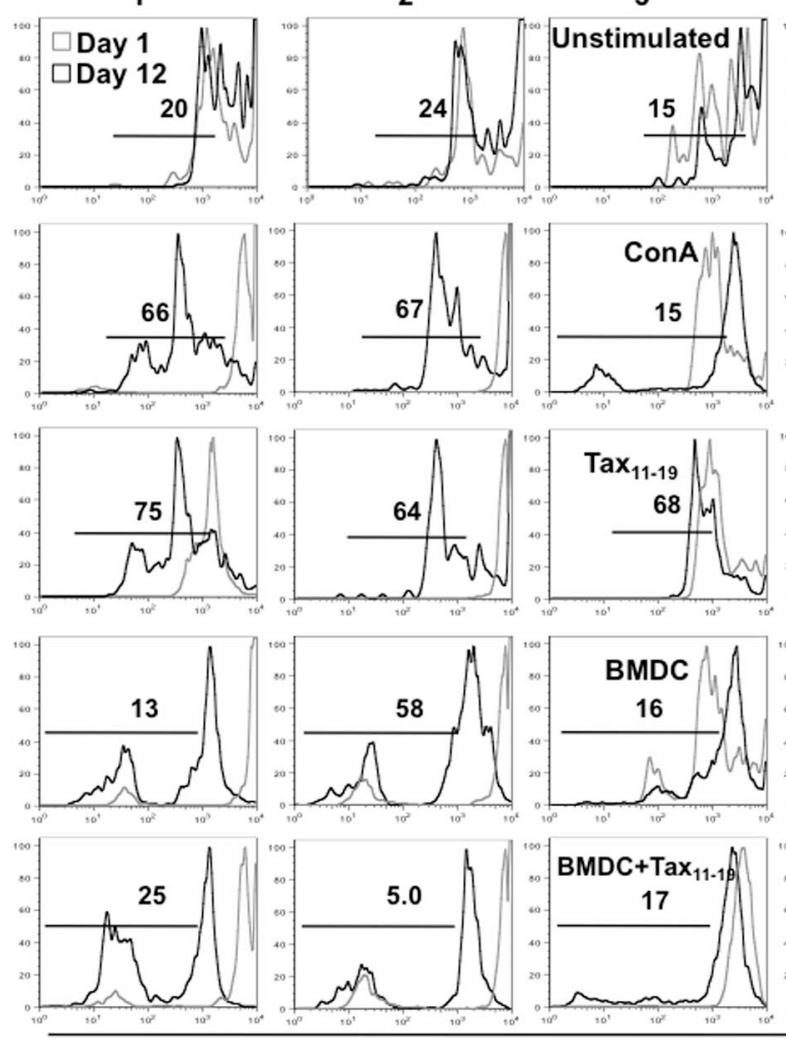

B
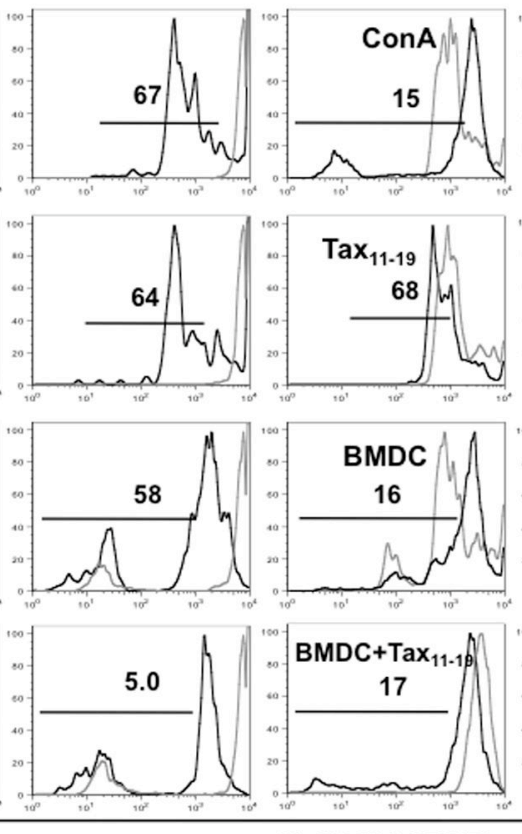

$\% \mathrm{CD}^{+} / \mathrm{CFSE}^{+}$
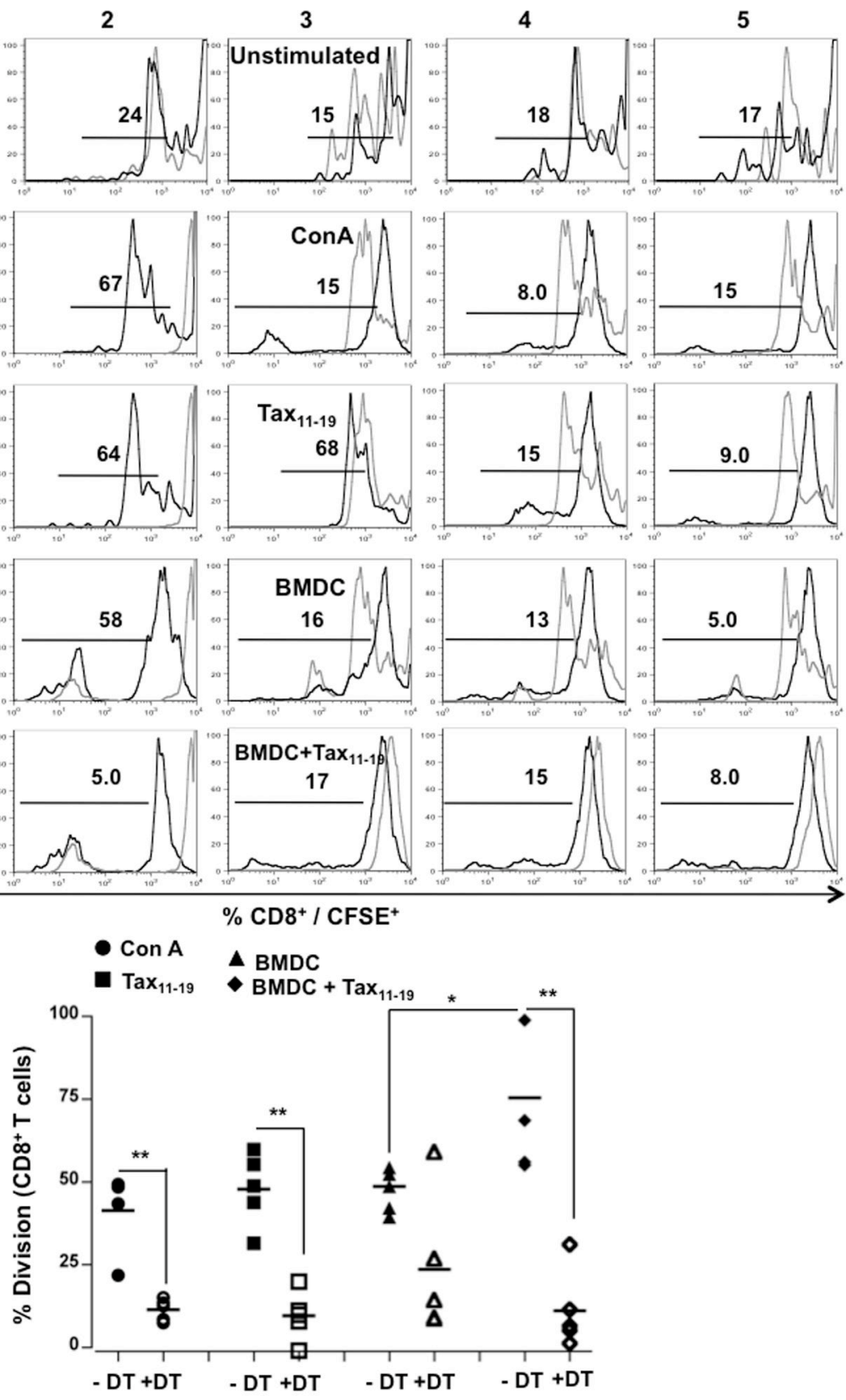

Figure 2. DC depletion in HLA-A2.1/DTR transgenic mice abrogates CD8 T-cell response to $\operatorname{Tax}(11-19)$ antigen

Mice were immunized with $\operatorname{Tax}(11-19)$ peptide along with tetanus helper peptide (THP) in the absence or presence of diphtheria toxin (DT) treatment as described in Materials and Methods. At the end of the experiment (day 5 after DT injection), both spleen and bones were harvested from each mouse. Bones were processed to obtain BMDCs as detailed in Materials and Methods. Splenocytes were CFSE labeled and co-cultured with Con A (1 $\mu \mathrm{g})$, Tax(11-19) peptide (100 nM), BMDCs alone, or BMDCs prepulsed with Tax(11-19) antigen in vitro. Cells from co-cultures were harvested at days 0 and 12 and stained with APCconjugated anti-mouse CD8 antibody and analyzed by flow cytometry. A total of 50,000 
events collected for each sample were gated to include the $\mathrm{CD}^{+} / \mathrm{CFSE}^{+}$population. Proliferation of $\mathrm{CD}^{+} \mathrm{T}$-cells at different conditions was analyzed by determining CFSE dilution into the daughter T-cells. Data presented indicate A) proliferation histograms from days 1 and 12 showing percent division at day 12 from nonimmunized mice; and B) percentage of dividing $\mathrm{CD}^{+} \mathrm{T}$-cells (\% Division) under all culture conditions from mice immunized with $\operatorname{Tax}(11-19)+$ THP in the absence or presence of DT administration. Percentage of division was obtained by calculating proliferation using the FlowJo 8.8.6 software and plotted as a graph showing the median value. Data are presented from five mice per treatment per injection group. The horizontal line in the graphs represents median values. P values for statistical comparisons within a group were calculated using two-tailed, nonparametric paired $t$ test (Wilcoxon); for comparisons between groups, values were calculated using two-tailed nonparametric unpaired $t$ test (Mann-Whitney). *P・0.05. ${ }^{*} \mathrm{P} \bullet$ 0.01 . 

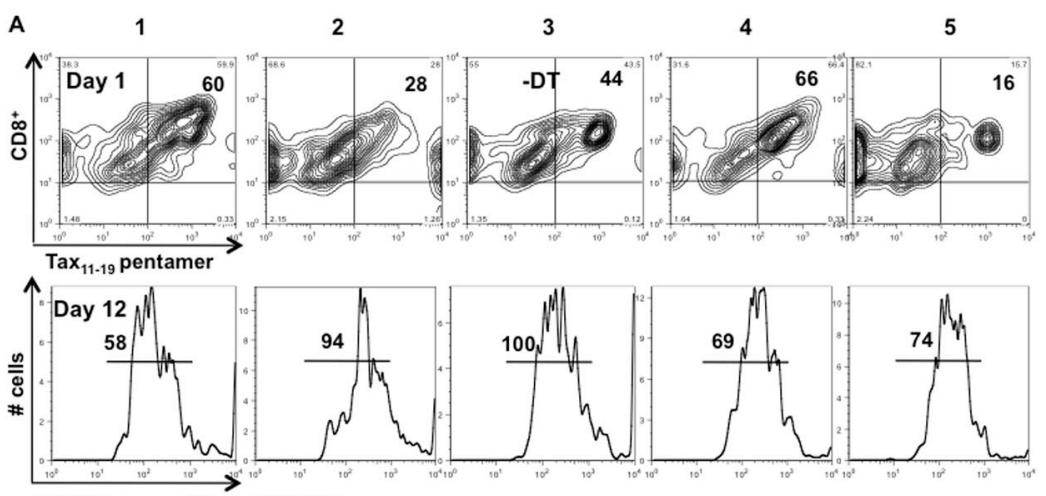
$\mathrm{CD}^{+} / \mathrm{Tax}_{11-19}$ pentamer $^{+} / \mathrm{CFSE}^{+}$
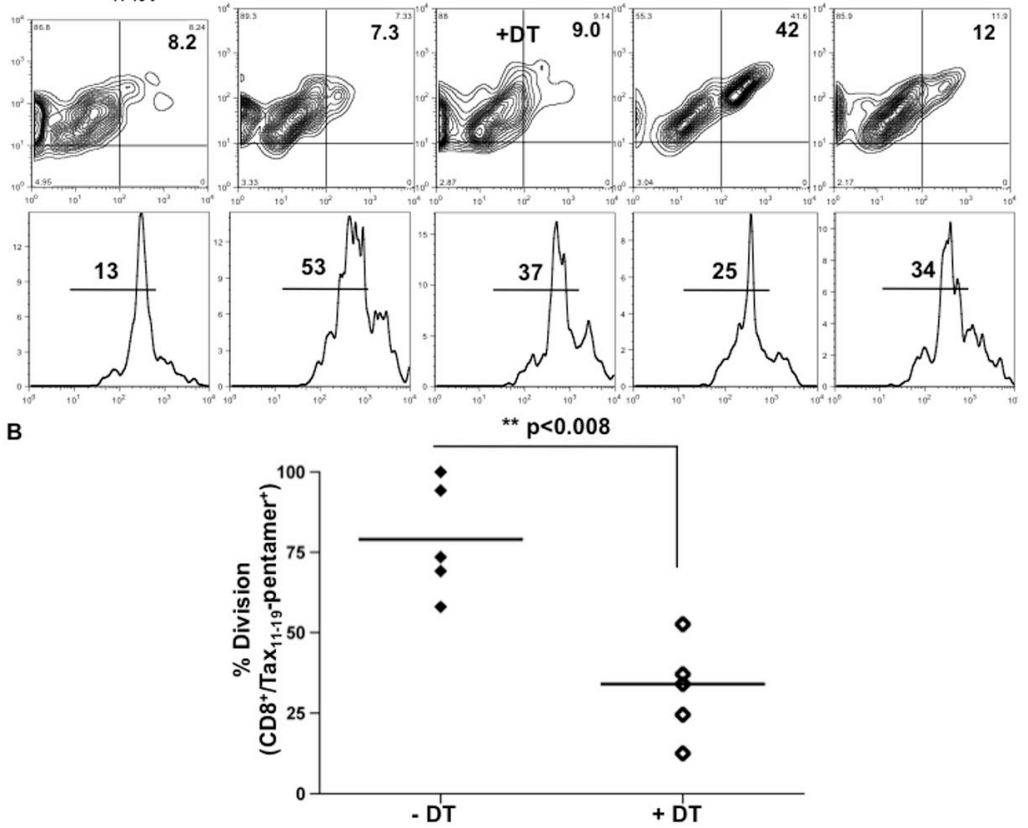

Figure 3. Antigen specificity of the observed responses based on the detection of $\operatorname{Tax}(11-19)$ pentamer-positive cells

Mice were immunized with $\operatorname{Tax}(11-19)$ peptide along with tetanus helper peptide in the absence or presence of diphtheria toxin (DT) treatment as described in Materials and Methods. At the end of the experiment (day 5 after DT injection), both spleen and bones were harvested from each mouse. Bones were processed to obtain BMDCs as detailed in Materials and Methods. Cells from co-cultures between splenocytes and BMDCS or BMDCs preprimed with Tax(11-19) peptide were harvested at days 1 and 12 and stained with APC-conjugated antihuman CD8 Ab and PE-conjugated Tax(11-19) pentamer and analyzed by flow cytometry. A) $\mathrm{CD}^{+} \mathrm{T}$-cells labeled cells were used on day 1 for obtaining CD8 ${ }^{+}$T-cells/Tax(11-19) pentamer-positive cells from co-culture of splenocytes with BMDCs preprimed with Tax(11-19) antigen from non-DC-depleted and DC-depleted mice immunized with Tax(11-19) + THP. Proliferation of Tax pentamer-positive cells from these groups was then analyzed on day 12 by determining CFSE dilution as incorporated into the daughter T cells. B) Percent division (\% Division) comparison between non-DC-depleted and DC-depleted mice. Percentage of division was obtained by calculating proliferation using the FlowJo 8.8.6 software and plotted as a graph showing the median value. Numbers 
1-5 represent mice from each group. $\mathrm{P}$ values for statistical comparisons within a group were calculated using two-tailed, nonparametric paired $t$ test (Wilcoxon); for between groups comparisons, values were calculated using two-tailed nonparametric unpaired $t$ test (Mann-Whitney). $* \mathrm{P} \bullet 0.05 . * * \mathrm{P} \bullet 0.01$. 

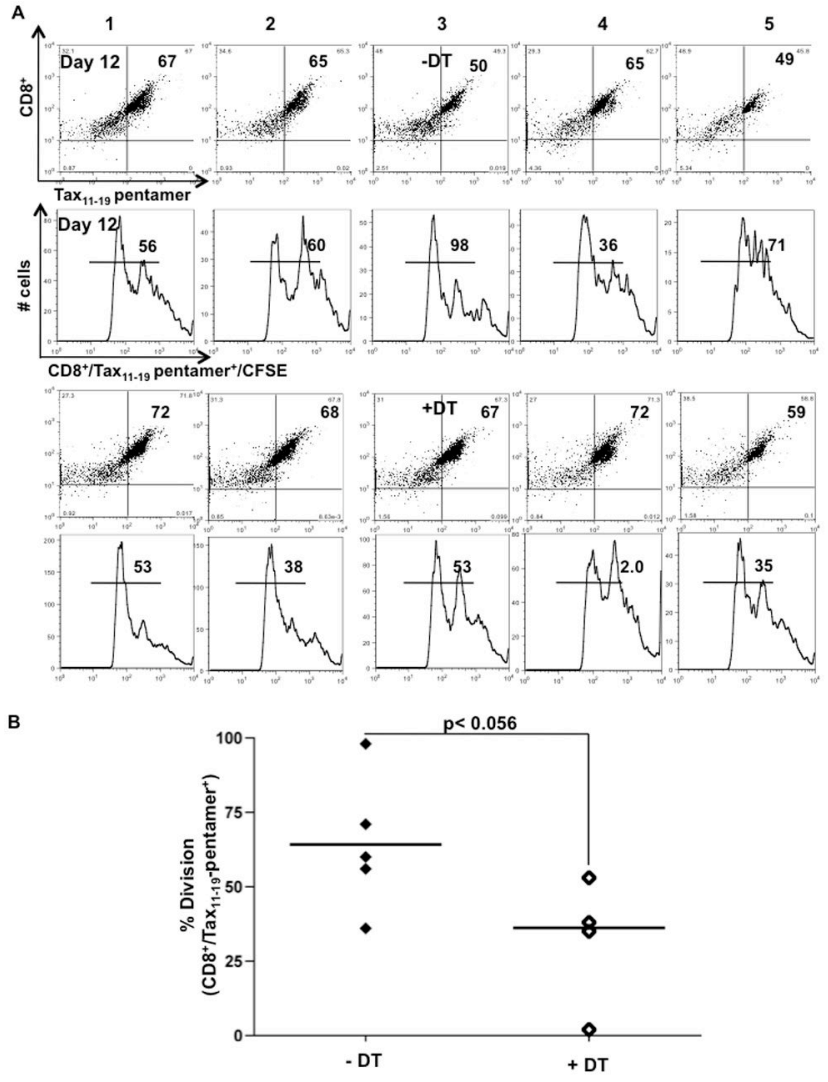

Figure 4. Detection of Tax(11-19) pentamer-positive cells in HLA-A2.1/DTR transgenic mice immunized along with the adjuvant

Mice were immunized with Tax(11-19) peptide along with tetanus helper peptide (THP) and incomplete Freund's adjuvant (IFA). Two additional groups of mice were given a uniform dose of diphtheria toxin (DT) (100 ng) prior to immunization. At the end of the experiment (day 5 after DT injection), both spleen and bones were harvested from each mouse. Bones were processed to obtain BMDCs as detailed in Materials and Methods. Cells from cocultures between splenocytes and BMDCS or BMDCs preprimed with Tax(11-19) peptide were harvested at day 12 and stained with APC-conjugated antihuman CD8 Ab and PEconjugated Tax(11-19) pentamer and analyzed by flow cytometry. A) Labeled CD8+ T-cells were used for obtaining $\mathrm{CD}^{+} \mathrm{T}$-cells/Tax(11-19) pentamer-positive cells from co-culture of splenocytes with BMDCs preprimed with Tax peptide from Tax(11-19) in conjunction with THP and IFA without (upper panel) and with (lower panel) DT administration. CFSE dilution histograms were obtained from the Tax(11-19) pentamer-positive population. B) Percentages of dividing CD8 ${ }^{+}$T-cells/Tax pentamer-positive cells (\% Division) on day 12 of BMDC plus Tax(11-19) co-culture were plotted to compare DC-depleted and nondepleted groups of mice showing the median value. Numbers $1-5$ represent mice from each group. $\mathrm{P}$ values for statistical comparisons within a group were calculated using two-tailed, nonparametric paired $t$ test (Wilcoxon); for comparisons between groups, values were calculated using two-tailed nonparametric unpaired $t$ test (Mann-Whitney). *P • 0.05. **P • 0.01 . 
A

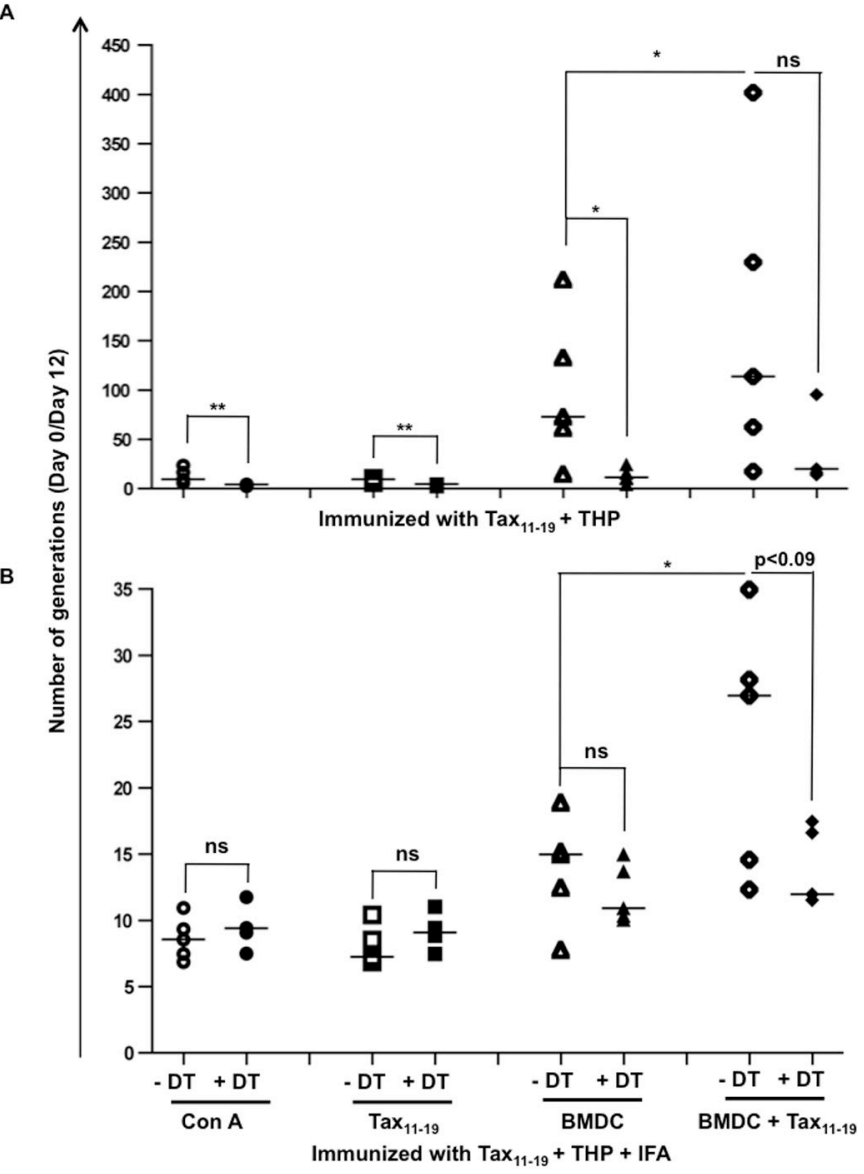

Figure 5. CD8 $^{+}$T-cell proliferation in mice immunized with Tax(11-19) peptide in presence or absence of adjuvant

Mice were immunized with $\operatorname{Tax}(11-19)$ peptide along with tetanus helper peptide in the absence or presence of incomplete Freund's adjuvant (IFA) as described in Materials and Methods. Two additional groups of mice were given a uniform dose of diphtheria toxin (DT) (100 ng) prior to immunization. At the end of the experiment (day 5 after DT injection), both spleen and bones were harvested from each mouse. Bones were processed to obtain BMDCs as detailed in Materials and Methods. Splenocytes were CFSE labeled and cocultured with Con A (1 $\mu \mathrm{g})$, Tax(11-19) peptide or BMDCs alone or BMDCs prepulsed with Tax(11-19) antigen in vitro. Cells from co-cultures were harvested at days 0 and 12 and stained with APC-conjugated anti-mouse CD8 antibody and analyzed for the CD8 ${ }^{+}$T-cell/ $\mathrm{CFSE}^{+}$population by flow cytometry. Proliferation of $\mathrm{CD}^{+} \mathrm{T}$-cells at different conditions was analyzed by determining CFSE dilution into the daughter T-cells. The number of generations (n) was calculated on the basis of reduction in the CFSE fluorescence in comparison to basal CFSE labeling ( $\mathrm{n}=$ geometric mean fluorescence intensity at day 0 / geometric mean fluorescence intensity at day 12) and plotted as a graph showing the median value. Data indicate proliferation in mice immunized A) without and B) with IFA for both - DT and +DT groups. Data are presented from five mice per treatment per injection group. $P$ values for statistical comparisons within a group were calculated using two-tailed, nonparametric paired $t$ test (Wilcoxon); for comparisons between groups, values were 
calculated using two-tailed nonparametric unpaired $t$ test (Mann-Whitney). $* \mathrm{P} \bullet 0.05$ and $* * \mathrm{P} \cdot 0.01$. 
A

\begin{tabular}{|c|c|c|c|c|c|c|c|c|c|c|c|c|}
\hline ID & IL-2 & IL-4 & IL-5 & IL-6 & IL-10 & IL-12 & IL-13 & IL-17A & IL-23 & IFN- $\gamma$ & TGF $-\beta$ & TNF- $\alpha$ \\
\hline \multicolumn{13}{|c|}{ PBS injected } \\
\hline -DT & ND & ND & ND & ND & ND & ND & $\mathrm{ND}$ & 0.5 & ND & ND & 20 & ND \\
\hline \multicolumn{13}{|c|}{$\operatorname{Tax}_{11-19}+\mathrm{THP}$} \\
\hline -DT & ND & ND & ND & 2.1 & ND & ND & ND & ND & ND & ND & 17 & ND \\
\hline$+\mathrm{DT}$ & ND & ND & ND & 127 & ND & 0.8 & ND & 0.5 & ND & ND & 19 & ND \\
\hline \multicolumn{13}{|c|}{ Tax $_{11-19}+$ THP + IFA } \\
\hline -DT & ND & ND & ND & ND & ND & 0.2 & $\mathrm{ND}$ & 0.8 & ND & ND & 10 & $\mathrm{ND}$ \\
\hline$+\mathrm{DT}$ & ND & ND & ND & 2.0 & ND & 0.6 & ND & ND & ND & ND & 8.8 & ND \\
\hline
\end{tabular}

B

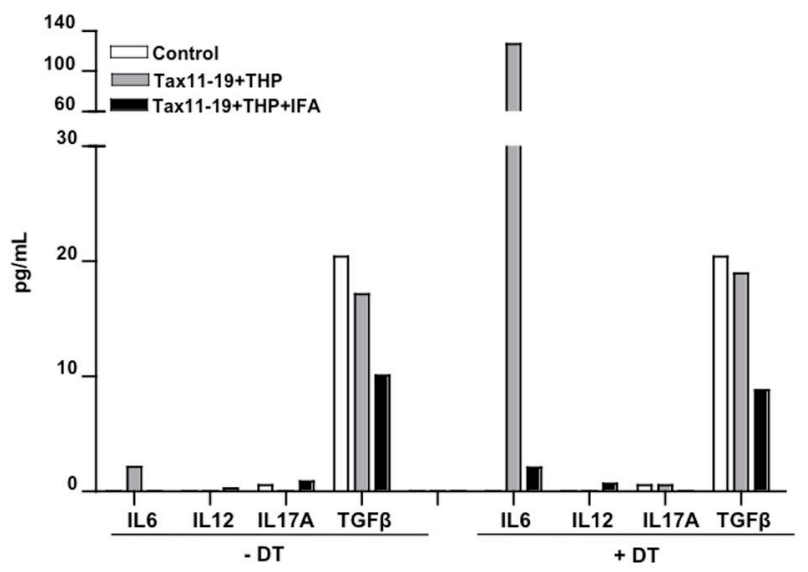

Figure 6. Serum cytokine profiles of DC-depleted and non-depleted transgenic mice immunized with or without adjuvant

Serum samples from mice were analyzed for cytokines using a Multi-Analyte ELISA Array (Qiagen, Germantown, MD) as described in Materials and Methods. Th1-related cytokines such as IL-2, IL-10, IL-12, IFN- $\gamma$, and TNF- $\alpha$; Th2-related cytokines such as IL-2, IL-4, IL-5, and IL-10; and Th17-related cytokines such as IL-13, IL-6, IL-17A, IL-23, TNF-a, and TGF- $\beta$ were detected using appropriate detection antibodies. The table in A) shows the observed values for all cytokines ( $\mathrm{pg} / \mathrm{ml}$ ). Bar graphs in B) depict relative levels of detectable cytokines in serum between differently immunized mice in the absence or presence of DC depletion. Absorbance was then read at $450 \mathrm{~nm}$ within $30 \mathrm{~min}$ of stopping the reaction. ND, not determined. 